\title{
The spirit of criticism in Buddhism
}

\section{by Jikai Fujiyoshi}

The spirit of criticism has a wide meaning. However, the original word for criticism is krino in Greek which means to divide. Therefore criticism, as the original word suggests, means to analyze the element of some fact or theory, recognizing the meaning and value of each of the parts, and to clarify their relation to the whole meaning. Although criticism means to evaluate the object which is criticized, the main function of criticism is to clarify the meaning of some fact or theory and to make clear the logical ground for its existence.

Criticism from the standpoint of form is divided into two kinds, lower criticism and higher criticism. Criticism from the standpoint of substance is also divided into two kinds, transcendent criticism and immanent criticism. Lower criticism means textual criticism and the explanation of literary materials such as books and manuscripts. Higher criticism means to clarify the genuineness of a work and to evaluate its historical value. Transcendent criticism criticizes facts or theories from the totally separate standpoint of a critic. Immanent criticism means that the critic enters into the thing which is criticized, amplifying and developing it by himself, determing whether any contradictions or confricts are to be found or not. Immanent critidsm is therefore much more essential than transcendent criticism.

The spirit of critcism sharply contrasts with dogmatism and contradicts skepticism. Dogmatism is the attitude of thought in which a dogma or doctrine is 'so firmly established that it rejects criticism. While skepticism means seeking after truth, mere seeking after truth without criticism always falls into doubt. If the spirit of criticism is feeble, either one will remain easily in dogmatism or one will fall into doubt. It was a epockmaking fact in the history of philosophy that in the 18th century in Europe Emanuel 
Kant, warning both dogmatism and skepticism, established the philosophy of criticism.

In this paper I would like to deal with how such a radical spirit of criticism functions in the field of Buddhism, which is one of the most philosophical world religions and contains in it a number of literary expressions. One has to notice how such a spirit of criticism has contributed to Buddhism as such.

Firstly, the spirit of criticism is found in the mental process of seeking. after truth not only of the Buddha himself but also of other Buddhists and is clearly found as well in their religious methods. In the case of Buddha, there are many opinions concerning his great renunciation of the world. However, there is no denying the fact that he made his final decision the sacred seeking or the profane seeking. This is found in Ariyaparyesanasutta. The criterion of the criticism of both the sacred seeking and the profane seeking is neither mere reason nor feeling, but is rather something of total man. There is a sharp flash of the functioning of his spirit of criticism combined with his earnest desire to seek after truth. Gotama Buddha, who entered the priesthood, could not be satisfied with the training and the attainment he received under the guidance of two meditationists. Therefore he left them and became an ascetic, but he could not be satisfied with ascetic training either. He then went after recovering his health to the place of his final awakening. There are many descriptions in Buddhist texts about how he attained the final awakening by means of deepening his self-realization. We can find a sharp flash of the functioning of his spirit of criticism in his religious method. From meditatation to asceticism, from asceticism again to meditation, his religious method has changed. However, there must be a firm reason for the change of his religious method. We can find his immanent criticism of the religious method of two meditationists and in his reflection on asceticism. There are some qualitative differences betweem meditation under the guidance of the two meditationists and his meditation at the place of his final awakening.

The Buddha's spirit of criticism is found not only in his process of 
seeking after truth but also in his attitude toward the sermon and his method of propagation. It is also found in his attitude of criticism toward the contemporary thoughts of India. His keeping silent to the methaphisical questions does not mean the frustration of his spirit of criticism, rather it means his guidance how to ask or what interst should one have.

Secondly, the spirit of criticism is found in the development of the Buddhist thought. It appeared either in the form of self-criticism of the Buddhist thoughts. Though it is found in scriptures and treatises made in India, in these texts it did not clearly take the form of criticism. It is rather found indirectly, through illustration or fiction. The differences between Mahāyāna and Hinnayāna, between Ekayāna and Triyāna and so on have been described. The characteristic of the spirit of criticism in Buddhism could be found in such a function of the spirit that when Buddhism meets other kinds of culture or religion it either inclusively comprehends them or exclusively rejects them. Further, it may be found in the form of criticism and classification of the Buddhist doctrines which were handed down from olden times and in the form of the synthetic comprehension of them as well. When the spirit of criticism functioned Buddhism always developed and took new forms. After Buddhism was transmitted into China the spirit of criticism of Buddhism functioned in the unique form of the so-called Kyōsō-Hanjaku 敉相制釋 (classification and criticism of the Buddhist doctrines). Kyōsō-Hanjaku or simply called Kyōhan 呚制 is the classification of various Buddhist doctrines but it contains the functions of criticism and synthetic judgment. Moreover, a synthetic view of Buddhism was established through such a criticism, and a new sect or school was erected based on this view. Whenever and wherever the spirit of criticism functioned Buddhism has vividly developed. But, whenever the spirit slept Buddhism was fixed and could not develop. Moreover, Buddhism swallowed various impurities and came to lose its own purity. It is said that these phenomena depend on the toleration of Buddhism, however, it is mostly originated in the lack of the spirit of criticism.

Modern rationalism is removing various medieval elements from Bud- 
dhism, so that Buddhism must be dressed in a new style of clothes. However, the basic spirit of Buddhism is not a mere rational something. On the contrary, the essence of Buddhism seems to be found far beyond the rational. Therefore, Buddhism as such can not be totally criticized by mere human-reason. The fact that the essence of Buddhism can not be grasped by mere reason but must be grasped by the religious act of a total man indicates that the essence of Buddhism is not a mere something rational. The thing which is called the Buddhist subject cannot be realized by mere reason or feeling but is self-realized through the religious act of a total man. The Buddhist subject is also named 'śūnyatā-subject' or 'Musubject' or 'Formless self'. It is subject so that it is living and functioning. As it is sometimes called Chitai-Hiyu 智體悲用 'prajñā-subject karūṇa-function', the Buddhist subject is prajñā and its function is karūna. Unless the Buddhist subject is prajñā it cannot function freely as karūna. The Buddhist subject which is composed of prajñā and karūna is full of the spirit of criticism. The criticism of the actual world by such a Buddhist subject is very radical. However, it does not merely negate many things in the actual world but also revives them as new reality from the higher standpoint. Shinkū-myōu 眞空妙有 'true śūnyatā subtle function', or Ōsō soku Gensō 往相郎還相 'going to the Pure Land from this world is coming back to this world from the Pure Land', these common expressions in Buddhism indicate nothing else than this fact. We can say that this is the characteristic of the Buddhist subject.

When Buddhism was introduced into China proper, it could not amalgamate directly with Han culture, but was amalgamated with something like sage worship and magical thought. As Dr. Zenryu Tsukamoto has indicated already, the Han intelligentsia who were actualistic and rationalistic could not agree with Buddhism except two points that the Buddha himself was born in a family of kṣatriya which is akin to that of Han intelligentsia and that he became a Buddha or a awakened man through study and discipline. Renunciation of the family and the abandanment of worldly desire, shaving head and becoming a monk, these are common in Buddhism. Ho- 
wever, for the Han intelligentsia who were educated by Confucianism to respect worldly ethics such Buddhist customs which seem to negate worldly ethics could not be accepted. Therefore the irrational moment of Buddhism could not be accepted by Confucians who are rationalistic in general. But Buddhism seems to have amalgamated with the atmosphere of Shinshenhōjutsu 神仙方術 (sage worship and magical thought) in late Han Dynasty at which time Confucianism was declining. At that time there were many magicians among Buddhist monks who came to China from India. Therefore Buddhism was accepted by means of the sage worship and magical thought into the society in which Huang ti 黄帝 and Laotzu 老子 were worshiped as Gods. At the time of political destruction of late Han Dynasty the spirit of criticism based on the Confucian rationalism was feeble and irrational Taoism which was amalgamated with various magical and mystical faiths was dominant. Therefore a new religion in which the teaching of a Godfied Buddha was preached by Buddhist monks who renounced worldly desires and looked like the Taoist magicians prevailed in the society of the common people when the political condition was unsettled and the spirit of criticism was feeble.

In the Wei and Chin Dynasties, as many Buddhist texts were translated into Chinese, Buddhism was studied but it became Taoistic and philosophical. And Buddhism was gradually accepted by many Confucians who were highly educated and respected Chinese classics. In this case, we have to notice that the Buddhist texts which were translated into Chinese were treated and authorized as Chinese classics. In the history of Chinese Buddhism, the first chinese monk who accepted Buddhism through his sharp spirit of criticism was Tao-an 道安 (314-385). His spirit of criticism can be found in his careful attitude as the first cataloger of Buddist Chinese texts. It is also found in his critical attitude toward the contemporary way of studying Buddhism. Such a critical way of studying Buddhism was succeeded and developed by Kumārajīva and Hui-yüan. After Buddhism was introduced into China where practical and secular thought was dominant, Buddhism seems to have a much more unworldly character because Bud- 
The spirit of criticism in Buddhism (J. Fujiyoshi)

dhists tried to pretend themselves to be higher and much more sacred than Confucians or Taoists. The contemporary intellects studied Confucianism, Taoism and Buddhism in harmony. However, their spirit of criticism was not strong enough to establish their own philosophy or system of thought. Even a number of famous intellects were still sticking to the Chinese classics, without any spirit of criticism. Lacking of earnest desire of practice, they merely indulged themseves in literary enjoyment. In such an atmosphere Buddhism could not escape from these trends of thought. The harmonious trend of three schools of thought was cherished in such an atmosphere, but it was no more than mere eclecticism or syncretism. Many disputes had taken place among these three schools of thought. However, the characteristic of those disputes was that they were harmonious in general. No exclusive sharp spirit of criticism could not be found in them. It is because of these facts that Asiatic religions are generally tolerant and Buddhism itself has a strong flexibility. But, in fact, it is also because of this that Buddhism itself was not so deeply understood and was not crystallized to the form of practice which is exclusive in general.

Buddhism in the period of North and South Dynasties is characterized by Kyōsō-hanjaku (Classification and critical interpretation of Buddhhist doctrines). It is nothing else than to classify many Buddhist doctrines from one standpoint to criticize them to give a final decision. Therefore, it indicates one's own superiority over the many other doctrines. Further, it gives a logical ground upon which to establish a new school of Buddhism. In order to establish a new school of Buddhism Kyōsō-hanjaku is essentially necessary. There are many Kyōsō-hanjaku in Chinese and Japanese Bubbhism. We can trace a unique form of the spirit of criticism in those Kyōsō-hanjaku. However, I cannot deal with this subject in this paper because of the shortage of space. 